\title{
Analysis of the Reform of Rural Sociology in Agriculture Universities
}

\author{
Wang Yan \\ JI Lin Agriculture University \\ Chang Chun, China \\ yirenhaomeng@163.com
}

\begin{abstract}
The content of existing teaching materials of rural sociology is obsolete; fail to follow the rural society development. This paper expatriates current theme of rural social development, which is the urban-rural integration. Under such background, there is a lot of issues happened in rural areas, whereas the textbook authors cannot update these content. So we point out teaching problems. By integrating education resources, exploring advanced teaching method, adjusting teaching contents, optimizing the knowledge structure, strengthening the social practice teaching, and improving examination evaluation, and etc., we carry out the reform of rural sociology teaching in agriculture colleagues. That stimulates students' interest of learning rural issues and is useful to curriculum innovation.
\end{abstract}

Nowadays, the urban-rural integration has become a strategic objective of the state, which means the end of independent administration of cities and rural areas, and the beginning of promoting agriculture by industry, and promoting the rural areas by urban areas. It can be said that the country has been facing new development chances, and there should be a breakthrough in all aspects of economic outputs and social development. Under such background, we should analysis the content and method of the course of rural sociology; ponder the rural problems, such as rural land system, migration and employment, the equalization of basic public services, selforganization of farmers, and so on, in order to innovate the curriculum content of rural sociology.

Keywords-urban-rural integration; rural sociology; curriculum reform; agriculture universities

\section{THE NEW SCENE OF RURAL SOCIETY IN THE PROCESS OF URBAN AND RURAL INTEGRATION}

China has always been a big agriculture country, and the countryside has always been the foundation of Chinese culture and society. But with the deepening of reform and opening up, China's urbanization level has improved rapidly, more than half of the population living in cities rather than rural areas. In this process, a large number of farmers leave the piece of land that gave birth to him, so that the country life has undergone a qualitative change. From the perspective of rural economic development, the household contract responsibility system took the household itself as production units, bringing about the concerning of "self" and "private", consequently, the village became a "hallow village". From the perspective of social interaction, comparing from the Fei Xiaotong's native China theory, many scholars believe that rural areas has stepped into the stage of "post-rural China” or the "new-rural China”, from the acquaintance society to semi-acquaintance society[1]. From the perspective of social governance, villagers' self-governance system did not work as expected as a core system; instead, the village committee became a satellite of government, with administrative features, thus, villagers lost confidence and enthusiasm. In the process of governance, government plays the most important role, while other governance subjects do not work properly. That's why the governance effect is not good. In the process of social transformation, the interest conflicts and rural social issues are increasingly emerging. Under microscopic perspective, peasants' issue is the core of "three rural issues", and it is also the key point of urban-rural integration, so the problems of urbanization of migrant workers, relations between rural people and lands, and social relations should be concerned. Under medium perspective, the main problem is the current situation of social organization. For a long time, the level of peasants' organization is not very high, combined with the declined of traditional clan organization. Emerging organizations especially farmers' cooperative economic organization should undertake the responsibilities of developing rural economic, integrating villagers, and enhancing public life. On the macroscopic aspect, rural social management, rural social development, the rural social security, and other common problems become hot social issues.

\section{THE DILEMMA OF RURAL SOCIOLOGY DEVELOPMENT}

The study of agriculture sociology exhibits a characteristic which is there is multi experience but less theoretical paradigm. As described, there are a large number of issues to be resolved in the process of society transition in rural areas. Coupled with China's vast territory, the same problem in different regions may exhibit different characteristics. Scholars pursue research based on the endless emerging rural issues, and write lots of treatise. If only calculated the number of research results, rural sociology may be the branch of sociology with the most extensive treatise. With the booming of rural sociology, the research methods are no longer confined to the traditional anthropological case study, but begin to use sociological quantitative research methods. Although rural sociology has made rich achievement currently, there is still a problem in these researches, quoted Lu Yilong's saying, “too much empirical research and lacking theoretical paradigm” [2].

Many studies just repeat simple empirical research, with little theoretical construct. As Xu Xiong says, there are two aspects of problems; one is that there is too much literature 
study but little investigation; the other aspect is that there should be more classification study [3].”

The current situation of sociology study impacts disciplines and teaching work of sociology. Although the society change rapidly and there is a lot of findings, fortunately, these findings do not exist in teaching material as it came out for several years. The existing versions of sociological textbooks are many, but with the same stereotype system and little original. The lack of theoretical research makes it difficult to explain the actual situation in China. In this situation, students can only know about diverse issues themselves, with no guidance and explanation of theory. And also teaching method is obsolete. Rural sociology focuses on practical subject, but current teaching model demands teachers' teaching and students' listening just like other subjects, mainly represents passive study. Besides, extracurricular practice is ignored in teaching process for lacking funding and other reasons, students are not encouraged to carry out teaching practice, which is a pity for the development of rural sociology.

\section{EXPLORATION ON THE DIRECTION OF THE REFORM OF RURAL SOCIOLOGY COURSE}

\section{A. Firstly, updating teaching content}

In the course of urban and rural co-ordination, the government will release bonus and input a variety of resources to rural areas, and it have got more better basic facilities and new development of economic and society. Thus, the teaching content must be updated, according to the transformation of rural social structure and modernization process. Not all of present textbooks contain the content of recent social changes; most of them are still lagging behind, just giving a general introduction. Under the new situation, the construction of rural sociology should pay attention to the construction of teaching material; update teaching content, and optimize knowledge structure.

\section{B. Secondly, strengthening theoretical study}

Rural construction is a practical field, focusing on actual behaviors, whereas the development of rural sociology needs theoretical guidance to avoid unnecessary one-sidedness and blindness. For example, studying rural economic issues need the theory of property right and institutional economic; studying social governance need the theory of state-society. Lu Yilong pointed out that we must establish our own theory paradigm, using sociological methods to grasp the experiential fact, and making use of which to create our own theory [4].

\section{Thirdly, changing teaching method}

Apart from teaching content, the teaching method also needs to transform, because rural sociology has strong character of technology, practicing, and application. Using as much as heuristic and participatory method will stimulate students' interest in learning. In the aspect of teaching means, the traditional "force-feeding" teaching means should be changed. According to actual circumstances, using flexible methods, such as "special topic", "case teaching”, and "heuristic method", can arouse the enthusiasm of teachers and students, encouraging students participate in teaching[5].

Students-centered teaching method means it needs more pre-design, such as delicate discussing topic, which sets a higher demand for teachers.

\section{Fourthly, encouraging students carrying out social investigation}

Fei xiaotong's classic" native China” created a tradition that research study should be carried out first in rural areas. Research and application of sociology must have scientific; it needs students to use professional social survey research to find out and analysis issues. He Xuefeng has written an article on the relationship between empirical research and the localization of Social Science in China; and he also points out "current Chinese social science needs a rush to field experience” [6]. Practice teaching not only make students to grasp the systematic research methods and skills, to train students finding and observing problems, and to analyze and solve problems, but also make students truly understand and pay close attention to rural, and love rural areas.

\section{E. Finally, extended village Research Paradigm}

Paradigm refers to research examples which academic community approve, refer to, and apply with in a period of time. Until now Chinese rural sociology has already formed the village paradigm primarily. There are two kinds of village research paradigm. It is village ethnographic research, and "three rural issues" and strategy. Village research paradigm has a unique advantage of examining and understanding microstructure of rural society and local culture. But it cannot behalf the whole Chinese country, and can't deduce to the macro, if we put too much attention to micro village, it is hard to grasp the whole society, and limit vision of discipline. In the modern society with strong mobility, external changes may also affect the change of village, so we should pay attention to not only village itself but also outside world. We can also use quantitative research method. Compared with the field survey, quantitative investigation has the advantage of grasping overall features and developing trend.

\section{CONCLUSION}

Rural sociology is the branch discipline of sociology, studying rural structure, rural social relations and the development of the rural society. The content of rural sociology mainly contains three aspects, rural economic and social structure, social changing, and “three rural issues”. In recent years, there are many changes happened in urban and rural China, a large number of rural surplus labors have moved into cites, whereas some rural areas have been depressed, with a lot of unsolved problems, such as rural education, social security, public goods supply, environmental issues, left behind elderly, women, children, and so on, which hindered the ruralurban co-development. Rural sociology courses of Agriculture universities should focus on social reality, analyzing key issues more than ever, and arrange teaching content and methods reasonably. 
As a college student of rural sociology, it is better to go deep into the rural society and apply it to the analysis of social problems. The content of rural sociology of agriculture colleges should be more tightly around rural reality; attaches great importance to rural construction; and highlight the characteristic. The teaching, analysis, and application of rural sociology, will guide the construction of rural modernization in China; provide a scientific basis for making and carrying out policy; speed up the development of agricultural production and quality of rural life; and help maintaining rural social stability.

\section{REFERENCES}

[1] Lu Yilong. Basic problems and solutions of "Post-rural China”, Social Science Research, vol.1, 2015 (In Chinese).

[2] Lu Yilong. Beyond intuitive experience: rural sociology theory innovation, Tianjin Social Science, vol.3, 2010 (In Chinese).

[3] Zhang Jie. Post Native China: The new challenge of China's rural sociology, China's Social Sciences Press, 2015-2-13, version A02 (In Chinese).

[4] Song Hui. Study on the reform of rural sociology under the background of new rural construction, Anhui Agriculture Science, vol.39, 2011 (In Chinese).

[5] He Xuefeng. Returning to China's empirical research-The construction of localization of China's social science, Exploration and Contention, vol. 11, 2016. (In Chinese) 